\title{
Compensation or Social Investment? Revisiting the Link between Globalisation and Popular Demand for the Welfare State
}

\author{
MARIUS R. BUSEMEYER* AND JULIAN L. GARRITZMANN** \\ * Department of Politics and Public Administration, University of Konstanz, Fach D 79, \\ D-78457 Konstanz, Germany \\ email: Marius.Busemeyer@uni-konstanz.de \\ **Department of Political Science, University of Zurich, Affolternstrasse 56, CH-8050 Zurich, \\ Switzerland \\ email: Julian.Garritzmann@uzh.ch
}

\begin{abstract}
The debate on effects of globalisation on welfare states is extensive. Often couched in terms of a battle between the compensation and the efficiency theses, the scholarly literature has provided contradictory arguments and findings. This article contributes to the scholarly debate by exploring in greater detail the micro-level foundations of compensation theory. More specifically, we distinguish between individual policy preferences for compensatory social policies (unemployment insurance) and human capital-focused social investment policies (education), and expect globalisation to mainly affect demand for educational investment. A multi-level analysis of International Social Survey Programme (ISSP) survey data provides empirical support for this hypothesis. This finding provides an important revision and extension of the classical analytical perspective of compensation theory, because it shows that citizens value the social investment function of the welfare state above and beyond simple compensation via social transfers. This might be particularly relevant in today's skill-centred knowledge economies.
\end{abstract}

\section{Introduction}

Although it has been going on for a long time, the debate on the impact of economic globalisation on the welfare state is far from being settled. Often couched in terms of a battle between the compensation and the efficiency theses, the scholarly literature has provided contradictory arguments and findings on this complex association. Proponents of the compensation theory argue that globalisation increases popular demand for compensatory social policies so that highly open economies are often found to be the ones with the largest welfare states (e.g. Scandinavian countries or the Netherlands). In contrast, the efficiency thesis states that competition between nation-states for mobile capital delimits governments' leeway to increase revenues via taxation and therefore depresses 
public social spending. The existing empirical evidence is mixed, although there seems to be more support for the efficiency thesis in the recent period (see references below).

Rather than contributing to the somewhat deadlocked theoretical and empirical discussions on the 'compensation vs. efficiency' debate directly, the goal of this article is to advance scholarly knowledge by exploring in greater detail the micro-level foundations of compensation theory. Whereas the classical work in the field has mostly focused on the macro-level association between globalisation and the welfare state, more recent work has already moved towards the exploration of the micro-level of preferences, analysing the individual and contextual determinants of individual-level preferences for trade liberalisation and economic globalisation (e.g. Hays et al., 2005; Hays, 2009; Mayda and Rodrik, 2005; Mansfield and Mutz, 2009; Schaffer and Spilker, 2016). Surprisingly few studies (in particular Walter, 2010a, 2010b, 2017, but see also Balcells Ventura, 2006) have explicitly studied the impact of economic globalisation on the formation of social policy preferences, even though this is an important element of the compensation thesis.

Walter's (2010a, 2010b, 2017) important and influential work on this topic focuses on preferences for redistribution or social protection broadly defined. We argue in the present article that this focus is too broad and undifferentiated. More specifically, we distinguish between individual policy preferences for compensatory social policies (unemployment insurance) on the one hand and social investment policies (education) on the other. Based on multi-level analysis of survey data in 17 OECD countries, our core finding is that globalisation indeed increases individual-level support for more government spending on education, but not on unemployment. This finding is partly at odds with the logic of the compensation thesis, because it could have been expected that the effect of globalisation on purely compensatory policies should be stronger than the effect on social investment policies, since the latter do not necessarily compensate directly for negative side effects of economic globalisation. The purpose of this paper is therefore to revise, refine and extend the original analytical perspective of compensation theory, paying more attention to the role of the social investment function of welfare state policies.

\section{Globalisation and the welfare state: A brief literature review}

There is a huge literature on the relationship between economic globalisation and the welfare state (for overviews, see Brady et al., 2007; Genschel, 2004; Hays, 2009), which can be roughly divided into three camps. A first group could be named globalisation sceptics (Castles, 2004; Iversen, 2001; Iversen and Cusack, 2000; see Taylor-Gooby, 2002 for a critical perspective on this literature). In their view, socio-economic processes such as deindustrialisation and 
skill-biased technological change are more important driving forces of welfare state development than economic globalisation. Moreover, they claim that the politics of welfare state expansion and retrenchment play out in the arena of domestic politics and that constraints supposedly imposed by the dynamics of economic internationalisation are much less binding than assumed (see also Swank, 2002; Potrafke, 2009). Hence, institutions such as electoral and labour market institutions and the balance of power between domestic actors (political parties, trade unions, employers' associations, etc.) are believed to strongly condition the impact of globalisation forces on social policy-making (Swank, 2002; Hays, 2009; Starke et al., 2014).

In contrast, two other strands of literature agree that globalisation has significant effects on welfare states, but expect effects in opposite directions. The compensation thesis, going back to the work of Cameron (1978) and Katzenstein (1985), posits that economic globalisation leads to an increase in popular demand for social insurance, because individual workers exposed to the vagaries of international markets perceive amplified economic insecurity (Scheve and Slaughter, 2004) and demand compensation via the welfare state (more recent contributions are Garrett, 1998; Rodrik, 1997, 1998). The so-called efficiency thesis states the opposite view (Kurzer, 1991; Scharpf, 1991): economic globalisation constrains public spending in general and on welfare in particular because competition for mobile capital triggers a 'race to the bottom' between nation-states (Genschel, 2002): As firms in internationalised markets can credibly threaten to withdraw capital, governments are expected to react to these threats by decreasing the firms' costs, especially taxes. Decreasing tax revenues, in turn, make cuts in (social) spending more likely.

The empirical evidence on the macro-level is mixed (Benarroch and Pandey, 2012; Brady et al., 2005; Brady et al., 2007; Burgoon, 2001; Garrett, 1998, 2001; Garrett and Mitchell, 2001; Potrafke, 2012; Leibrecht et al., 2011). Some scholars confirm the existence of a positive association between economic globalisation and welfare state generosity (Garrett, 1998; Garrett, 2001; Rodrik, 1998; Meinhard and Potrafke, 2012), whereas others find support for the efficiency thesis (Busemeyer, 2009; Jahn, 2006; Marshall and Fisher, 2015). More recently, scholars argued that one way of reconciling the competing claims is to think of the effect of globalisation as variable over time - it might be that the nature (or intensity) of economic globalisation changed at some point in time (Busemeyer, 2009; Hicks, 1999; Jahn, 2006).

Recent scholarship has also significantly expanded our knowledge about the micro-foundations of the globalisation-welfare nexus. Scheve and Slaughter (2004) prepare the ground by showing that - supporting compensation theory globalisation increases individual perceptions of economic insecurity. Balcells Ventura (2006) finds that trade openness fuels demands for redistribution but that these demands are moderated by a country's economic wealth and the 
relative size of sectors losing from free trade. Taking this argument further, Walter (2010b) analyses the impact of openness on individual social policy and partisan preferences in the case of Switzerland. She shows, in line with compensation theory, how exposure to international competition makes individuals more likely to demand social insurance and that this demand in turn affects partisan choices during elections. In a related paper using data for a larger set of European countries from the European Social Survey (ESS), Walter (2017) finds that the effects of globalisation are mediated by individuals' skill profiles: low-skilled individuals exposed to the economic forces of globalisation are more likely to perceive greater labour market risks and demand social protection than highskilled individuals.

In general, however, and in particular compared to the wealth of studies on the macro-level association between globalisation and the welfare state, the micro-level foundations remain under-researched. This is surprising, because the compensation thesis explicitly develops the argument that globalisation should first and foremost enhance popular demands for social protection, so that, eventually, a more generous welfare state regime will boost support for a further liberalisation of trade (Hays et al., 2005; Hays, 2009). Rather than exploring attitudes towards particular social policies, most of the work on the micro-level foundations of economic trade theories has focused on explaining individual trade policy preferences (Mayda and Rodrik, 2005; Mansfield and Mutz, 2009; Schaffer and Spilker, 2016). Understanding the compensation argument, in its entirety, requires confirmation not only of the link between welfare state generosity on the macro-level and individual-level support for trade liberalisation, but also of the consequences of economic globalisation for popular demand for social policies. The important contributions by Walter (2010a, 2010b, 2017) are a first step towards filling this research gap on the link between globalisation and social policy preferences. However, these studies focus on popular support for redistribution or social protection more generally defined. This broad focus glosses over important differences between different kinds of social policies (see also Burgoon, 2001): in particular, the distinction between compensatory social policies more narrowly defined and policies geared at the provision of human capital.

\section{Globalisation and demand for different types of social policies}

Similar to compensatory social policies, social investment policies promoting human capital formation might play an important role in cushioning the negative side effects of economic globalisation. Recent work in comparative welfare state research emphasises that the welfare state does not only compensate for income and job loss via social transfers, but also promotes the formation of human capital via education, training and active labour market policies in order to 
'prepare' individuals for labour market participation. This is in order to try and avoid the 'repairing' of labour market risks ex ante (Bonoli, 2013; Hemerijck, 2013; Morel et al., 2012; Van Kersbergen and Hemerijck, 2012). In line with this way of thinking, some studies have provided initial evidence of a positive association between economic globalisation and spending on education at the cross-country level (Ansell, 2008, 2010; Boix, 1998; Dreher et al., 2008), but the causal mechanisms behind these associations remain underdeveloped and the evidence is not conclusive. ${ }^{1}$

Contributing to, but also moving beyond, the existing literature on the effects of globalisation on the micro-level of policy preferences, this paper broadens the traditional perspective of the compensation thesis by paying greater attention to the dual function of the welfare state: compensation and human capital formation. By exploring the varying association between globalisation and welfare state support across a range of policies, we follow in the footsteps of the important work of Burgoon (2001). In spite of the fact that his empirical analysis focuses on macro-level aggregate data rather than micro-level survey data, Burgoon's theoretical argument is that the association between globalisation and welfare state politics should be stronger 'the closer the connection of a program to the direct and near-term needs of working people made vulnerable by openness' (Burgoon, 2001: 521). In line with this argument, Burgoon expects that (both active and passive) labour market programmes should be particularly affected by globalisation as they 'provide the most immediate and direct relief for vulnerable groups' (Burgoon, 2001: 521). As education is less directly connected to the immediate needs of vulnerable workers, Burgoon expects a much weaker relationship between this policy and globalisation. In contrast, in the following section, we develop an argument as to why globalisation might have even stronger effects on support for education policy compared to traditional social transfers programmes since the development of human capital might be perceived as a more viable long-term strategy to face the challenges of economic internationalisation.

Traditional compensatory social insurance policies amount to an ex-post compensation of the negative effects of globalisation, i.e. increased labour market risk. Among different types of social protection policies, unemployment insurance is most closely related to the compensation argument, since other types of social insurance such as pensions and health care insure against life-course related risks that are less directly affected by economic globalisation (as also argued by Burgoon, 2001). The availability of generous unemployment insurance might indeed enhance individuals' willingness to accept higher average levels of labour market risk. But if unemployment actually occurs, individuals only receive a partial compensation of their lost income and this only for a limited amount of time. Also, longer spells of unemployment have negative repercussions for other forms of social insurance, in particular pensions. 
Therefore, individuals might alternatively favour a pro-active approach when dealing with the challenges of economic globalisation. Rather than demanding ex post compensation for globalisation-related job losses, working-age individuals might be interested in upgrading and updating their skills via further training or education in order to prevent job loss ex ante. Investing in human capital boosts individuals' employability, acting as an effective form of insurance against changing labour market demands (for a related argument regarding the impact of deindustrialisation, see Jensen, 2011). Since individual decisions on human capital investment also depend on the availability of such opportunities, we expect that individuals confronted with the economic forces of globalisation will demand more government spending and involvement in the provision of human capital.

What is more, from a political perspective, it could be argued that economically weak and vulnerable groups - the globalisation 'losers' - are also weak politically (Emmenegger et al., 2015), and therefore, in the aggregate, the demands from the middle class for more investments in human capital might dominate demands from the economically vulnerable groups for compensation via social transfers. In line with this thought, work by Van Oorschot (2006) on deservingness shows that the unemployed are generally perceived as least deserving of support via social policies compared to other groups. Of course, it is important to recognise that the group of those affected by and vulnerable to globalisation is larger than the group of unemployed people (and not all of the unemployed lost their job because of globalisation). Nevertheless, following the basic logic of economic trade theory (in line with Hekscher and Ohlin, Ricardo and Viner, and Samuelson and Jones trade models), it is plausible to expect that globalisation in advanced democracies will further erode the labour market position of those who are already disadvantaged. This in turn affects their political power and the degree to which their particular demands for compensatory policies are eclipsed by demands from the middle classes to support social investment policies.

Finally, individual-level support for public educational investments could also be fuelled by 'sociotropic' perceptions (Mansfield and Mutz, 2009) about the link between globalisation, education, and the welfare state. Sociotropic perceptions refer to perceptions about 'how trade affects the country as a whole' (Mansfield and Mutz, 2009: 427), i.e. individual perceptions about how policies and other macro-level factors influence the wealth of the economy as a whole independent of the individual's own situation. For instance, parents (in globalised economies) can be expected to demand educational investments in order to ensure that their children are able to deal with the challenges of internationalised, skill-intensive labour markets. From that perspective, but also depending on the individual's labour market position, expanding educational opportunities for the next generation would be more attractive than compensating current globalisation losers by increasing spending on unemployment insurance. On the 
societal level, individuals might believe that expanding and improving their country's stock of human capital is more likely to contribute to continued growth than investing in passive transfer payments - particularly so in the 'age of the knowledge-based economy'. Assuming (although this may be a strong assumption) that individuals are aware of the implications of human capital investments for the future economic wellbeing of their country, a higher degree of exposure to economic globalisation could go along with more support for continued investments in human capital formation. This may be because the public is more aware of the positive linkage between education and economic growth in globalized, as compared to protectionist, countries.

We further hypothesize that the effects of economic globalisation percolate from the macro- to the micro-level rather than being confined to the microlevel only. To clarify, we argue that differences in openness across countries are more important than individual-level exposure to globalisation pressures. Individuals in open economies are expected to demand more government investment in human capital on average compared to individuals in closed economies, independent of whether they themselves work in the sheltered or exposed sector. This logic is somewhat different from Walter's (2010a, 2010b, 2017) approach, which identifies individuals' exposure to globalisation as a crucial determinant of redistributive preferences. While we see and agree with the logic of her argument, we believe that the macro-level context in a given political economy is even more important for the reasons outlined above. Even if they themselves are not directly affected by globalisation, individuals in open economies will most likely favour public investments in human capital, because they might realise that their jobs in sheltered parts of the economy (e.g. in the public sector) ultimately also depend on the competitiveness of the open sectors. Furthermore, when they have children, individuals in open economies are more likely to demand educational investments for their children since chances are high that they will end up in the open sections of the economy later on. Finally, we believe that a toostrong focus on individual exposure to globalisation underestimates the linkages between individuals in households. In the case of Scandinavian countries, for instance, a typical pattern of labour market segmentation is that women work in the sheltered public sector, whereas men work in the exposed private economy.

Summing up, we extend the compensation argument by differentiating between different types of social policies: our core hypothesis is that individuals in open economies are expected to express a stronger demand for policies promoting human capital formation compared to individuals in more closed economies. The same could be expected of traditional compensatory policies (unemployment insurance), but we have argued that there are plausible reasons to expect that the link between globalisation and social investment policies will be tighter. Thus, our argument is an important modification of the traditional compensation thesis in the sense that, while also expecting that economic globalisation will increase 
public demands for government involvement, we think that these demands are mostly related to social investment rather than classical social transfer schemes.

\section{Empirical analysis}

\subsection{Data and methods}

The best available data to investigate the theorised relationship between economic globalisation and individual-level policy preferences are provided in the International Social Survey Programme (ISSP) Role of Government IV dataset for the year 2006 (ISSP Research Group, 2008). This dataset contains the following question:

'Listed below are various areas of government spending. Please show whether you would like to see more or less government spending in each area. Remember that if you say 'much more', it might require a tax increase to pay for it.'

This question is followed by a list of eight spending areas. Out of these, we picked unemployment benefits as the one that covers the traditional compensation argument best and education spending as a typical policy promoting human capital investment. We use each of these in turn as the dependent variable in order to address the question of whether the effects of globalisation vary across compensatory and investment policies. ${ }^{2}$

Respondents are asked to rank their spending preference on a 5-point scale from 1 (spend much more) to 5 (spend much less). We transform this variable into a binary variable in order to simplify the presentation, interpretation, and readability of our results. A value of 1 indicates a preference for 'more' or 'much more' spending, whereas a value of o stands for 'the same', 'less', or 'much less'. Substantively, it is plausible to assume that respondents will draw a line between a general support for spending increases, on the one hand, and indifference or a preference for lower spending, on the other. Empirically, however, we also tested other, non-dichotomised categorizations (see the Online Appendix, Supplementary Materials). We use multi-level logit random effects (RE) models to estimate the association between preferences and economic globalisation. In the robustness section (see the Online Appendix), we discuss alternative model specifications and operationalisations of the core dependent and independent variables in greater detail.

We focus on one common operationalisation of economic globalisation in the main analysis, namely TRADE OPENNESS, defined as the sum of exports and imports as per cent of GDP. Previous studies have shown that this measure has the strongest impact on social spending compared to alternative measures of economic globalisation such as the flow of foreign direct investments (FDI), imports from low-wage countries, or aggregated indices such as the KOF index of globalisation (Dreher et al., 2008). Nevertheless, we also test several alternative indicators of globalisation as well as levels and changes in globalisation in the 
robustness section, in order to see whether different 'faces' of globalisation affect attitudes differently.

We include a number of micro-level control variables. Table A in the Online Appendix presents summary descriptive statistics. INCOME, given in countryspecific income deciles, is expected to be negatively associated with support for public spending (Meltzer and Richard, 1981) as the wealthy dislike paying higher taxes for redistributive spending such as spending on unemployment benefits (using standardised income measures produces the same results). With regard to education, the effect of income is less straightforward, because the redistributive effects of education are more complex and unclear compared to other kinds of social policies (Ansell, 2008; Busemeyer, 2012; Garritzmann, 2015). The same applies to the impact of EDUCATIONAL BACKGROUND - usually, individual educational background is found to be negatively associated with support for redistribution (in our case: support for unemployment spending). When it comes to individual-level for education spending as a dependent variable, however, the association between spending support and educational background might be positive, because higher educated individuals recognise the value of educational investments for individual and societal progress. We measure this using 'educational years', but can produce highly similar findings when we focus on educational degrees instead. WOMEN are expected to be more supportive of public spending in general (Svallfors, 1997), although the exact causal mechanisms are not yet fully explored. With regard to the impact of AGE, we expect a negative association since older people do not benefit directly from increasing educational investments or unemployment spending (Busemeyer et al., 2009; Jensen, 2014). Moreover, we model the effect of age in a non-linear fashion (i.e. we include a squared term) to account for the fact that the effect of age might change for higher values.

Furthermore, it is important to control for whether a respondent has CHILDREN currently in education. Unfortunately, the ISSP does not offer a direct way to operationalise this, because it does not include an explicit question about whether respondents have children. Yet, the survey does offer information on respondents' household composition from which we can construct a measure of whether respondents live in a household with children or not. We use this as a proxy for 'having children'. Thus, we include a dummy for respondents who live in a single- or two-person household, which we use as a proxy for 'not living with children'. While this operationalisation is rather indirect, it will - if anything - underestimate the theorised effect, because respondents might live in a single- or two-persons household just because their children have moved out to study. We also tried other operationalisations, which all led to the same results (see robustness section). Finally, using the definitions supplied by the ISSP data, we include categorical measures for LABOUR MARKET STATUS (in additional models we also tested for the type of employment, as summarized below). 
In addition to these control variables, we also examined the impact of several rival explanations, e.g. respondents' ideological position, preferences towards public spending in general, religiosity, marital status, community status (ruralurban), and an occupation-based estimation of respondents' risk of becoming unemployed due to globalisation (Blinder's 2007 and Walter's 2010a 'offshoreability-index'). We discuss these in the robustness section below. Here, it suffices to say that the inclusion of these variables does not alter the main findings.

On the macro-level (countries), we control for the existing level of socioeconomic INEQUALITY (net Gini index; Solt, 2009) because this has consistently been argued and found to affect preferred spending levels. We expect that higher levels of inequality are associated with more demand for public spending in line with Meltzer and Richard (1981). Furthermore, a well-known problem with the specific wording of the spending questions in the ISSP survey is that it does not take into account existing cross-country differences in the status quo of public spending. Respondents are asked about their preferences for 'more' or 'less' spending, but not about the absolute amount of spending they would prefer. As is argued by Soroka and Wlezien (2010), existing expenditure levels can, however, trigger negative feedback effects, i.e. citizens are less likely to support further increases when spending is already high (and vice versa). Therefore, we also include the level of PUBLIC SPENDING in the respective field (as a share of GDP) as a macro-level control variable.

A vexing problem in the analysis of the micro-macro linkages between policy preferences and output is endogeneity, i.e. estimating to which degree policies affect preferences and how, in turn, preferences shape policy output. One possibility for solving the problem of endogeneity is to analyse the reciprocal interaction between preferences and output for individual country cases over time (as is done, for example, for three countries by Soroka and Wlezien (2010)) or to analyse exogenous shocks in natural experimental designs. Unfortunately, however, these approaches are much less feasible for broad cross-national comparisons because, due to limited data availability, there is essentially a trade-off between the number of cases that can be included in cross-sectional comparisons and the length of the time period under observation. The number of countries that participated in earlier Role of Government-waves is much smaller than in the current wave. Even in the 2006 wave, which is used in the present paper, the number of countries for which we have data on the important independent variables on the macro-level is only $17 .^{3}$

The established pragmatic solution to the endogeneity problem that we adopt here is to lag the core macro independent variables by five years: as the fieldwork for the survey was conducted in 2005/06, we use data on economic globalisation, inequality, and public spending in the respective fields from the year 2000. The time window of five years is, of course, arbitrary but it is quite plausible to assume that changes in macro-level contexts will take some time to 
affect preferences. As a robustness check, we used the 5-year average (2000-2004) in trade openness instead and found similar - though slightly less significant effects (cf. Online Appendix Table C for details). As a second test, we included values for the year 2005 (i.e. the year the survey was conducted) and did not find a significant association, which - while not being a strong causation test indicates that the effects of economic globalisation take some time to manifest themselves on the level of individual policy preferences. The Online Appendix presents (Table $\mathrm{C}$ ) and discusses these findings in detail.

\subsection{Results: Individual-level demand for compensation and investment}

Tables 1 and 2 present findings of multi-level logit random effects (RE) regressions. In table 1 , we focus on preferences for education spending and investigate the determinants of individual-level support, whereas in Table 2 we analyse determinants of support for unemployment spending.

Of crucial importance for our argument is the impact of trade openness on individual-level support for welfare spending. When included as the only macro variable (Table 1, model 1), the 5-year lagged level of trade openness has a positive effect on individual-level support for public education spending, but this effect is not statistically significant at conventional levels. As model 2 shows, the effect turns significant as soon as we control for the level of inequality in a country. This indicates that inequality works as a 'negative confounder' on the association between trade openness and preferences. Once this is accounted for, the effect of trade openness is very robust. The association remains robust when including the status quo in public education spending (model 3). Models 4 through 6 lend support to our proposition that the causal effect points from institutions to preferences and not the other way around, because the effects turn insignificant when we do not use the lagged (2000) but the contemporary (2005) levels of macro-variables.

The magnitude of the effect is sizeable. An increase in trade openness from the country with the lowest values (Japan, 21 per cent of GDP) to the most open economy (Ireland, 184 per cent of GDP), for example, is - according to Model 2 (while holding the controls constant) - associated with an increase in support for education spending from about 64 per cent to 86 per cent of respondents. Put differently, increasing trade openness by one standard deviation (i.e. 33 per cent) above the mean ( 72 per cent) increases public demand by slightly more than one standard deviation (i.e. to 76 per cent). The 95 per cent confidence interval ranges from 73 to 81 per cent. A similar increase in inequality by one standard deviation above the mean (i.e. from 30 to 34 per cent), is associated with an increase in demand for education spending from 72 to 81 per cent (the 95 per cent confidence interval ranges from 76 to 86 per cent), i.e. by almost two standard deviations. Thus, the change in predicted probabilities associated with an increase in trade 
TABLE 1. Determinants of individual-level support for more public education spending in 17 countries in 2005/06, multilevel logit model

(1)

(2)

(3)

(4)

(5)

(6)

Dependent variable: Individual-level support for 'more' or 'much more' government spending (=1) vs. 'the same', 'less', or 'much less' spending (=o) on education

Individual-level variables

\begin{tabular}{|c|c|c|c|c|c|c|}
\hline Income & $\begin{array}{l}-0.0086 \\
(0.0106)\end{array}$ & $\begin{array}{l}-0.0088 \\
(0.0105)\end{array}$ & $\begin{array}{l}-0.0085 \\
(0.0105)\end{array}$ & $\begin{array}{l}-0.0085 \\
(0.0106)\end{array}$ & $\begin{array}{c}-0.0086 \\
(0.0105)\end{array}$ & $\begin{array}{c}-0.0082 \\
(0.0105)\end{array}$ \\
\hline Female & $\begin{array}{c}0.0487 \\
(0.0377)\end{array}$ & $\begin{array}{c}0.0486 \\
(0.0377)\end{array}$ & $\begin{array}{c}0.0491 \\
(0.0377)\end{array}$ & $\begin{array}{c}0.0487 \\
(0.0377)\end{array}$ & $\begin{array}{c}0.0486 \\
(0.0377)\end{array}$ & $\begin{array}{c}0.0494 \\
(0.0377)\end{array}$ \\
\hline Education years & $\begin{array}{l}0.0269^{* * *} \\
(0.0051)\end{array}$ & $\begin{array}{l}0.0269^{* * *} \\
(0.0051)\end{array}$ & $\begin{array}{l}0.0269^{* * *} \\
(0.0051)\end{array}$ & $\begin{array}{l}0.0269^{* * *} \\
(0.0051)\end{array}$ & $\begin{array}{l}0.0270^{* * *} \\
(0.0051)\end{array}$ & $\begin{array}{l}0.0269^{* * *} \\
(0.0051)\end{array}$ \\
\hline Age & $\begin{array}{l}0.0224^{* * *} \\
(0.0069)\end{array}$ & $\begin{array}{l}0.0226^{* * *} \\
(0.0069)\end{array}$ & $\begin{array}{l}0.0226^{* * *} \\
(0.0069)\end{array}$ & $\begin{array}{l}0.0224^{* * *} \\
(0.0069)\end{array}$ & $\begin{array}{l}0.0225^{* * *} \\
(0.0069)\end{array}$ & $\begin{array}{l}0.0225^{* * *} \\
(0.0069)\end{array}$ \\
\hline Age (squared) & $\begin{array}{l}-0.0002^{* * *} \\
(0.0001)\end{array}$ & $\begin{array}{l}-0.0002^{* * *} \\
(0.0001)\end{array}$ & $\begin{array}{l}-0.0002^{* * *} \\
(0.0001)\end{array}$ & $\begin{array}{l}-0.0002^{* * *} \\
(0.0001)\end{array}$ & $\begin{array}{l}-0.0002^{* * *} \\
(0.0001)\end{array}$ & $\begin{array}{l}-0.0002^{* * *} \\
(0.0001)\end{array}$ \\
\hline No children & $\begin{array}{l}-0.2491^{* * *} \\
(0.0395)\end{array}$ & $\begin{array}{l}-0.2478^{* * *} \\
(0.0395)\end{array}$ & $\begin{array}{l}-0.2474^{* * *} \\
(0.0395)\end{array}$ & $\begin{array}{l}-0.2490^{* * *} \\
(0.0395)\end{array}$ & $\begin{array}{l}-0.2474^{* * *} \\
(0.0395)\end{array}$ & $\begin{array}{l}-0.2467^{* * *} \\
(0.0395)\end{array}$ \\
\hline Part-time & $\begin{array}{c}0.0915 \\
(0.0634)\end{array}$ & $\begin{array}{c}0.0911 \\
(0.0633)\end{array}$ & $\begin{array}{c}0.0910 \\
(0.0633)\end{array}$ & $\begin{array}{c}0.0917 \\
(0.0634)\end{array}$ & $\begin{array}{c}0.0919 \\
(0.0634)\end{array}$ & $\begin{array}{c}0.0917 \\
(0.0634)\end{array}$ \\
\hline Less than part-time & $\begin{array}{c}0.0650 \\
(0.0662)\end{array}$ & $\begin{array}{c}0.0649 \\
(0.0662)\end{array}$ & $\begin{array}{c}0.0647 \\
(0.0661)\end{array}$ & $\begin{array}{c}0.0652 \\
(0.0662)\end{array}$ & $\begin{array}{c}0.0638 \\
(0.0662)\end{array}$ & $\begin{array}{c}0.0634 \\
(0.0662)\end{array}$ \\
\hline Unemployed & $\begin{array}{c}0.0174 \\
(0.1051)\end{array}$ & $\begin{array}{c}0.0192 \\
(0.1051)\end{array}$ & $\begin{array}{c}0.0196 \\
(0.1051)\end{array}$ & $\begin{array}{c}0.0176 \\
(0.1051)\end{array}$ & $\begin{array}{c}0.0169 \\
(0.1051)\end{array}$ & $\begin{array}{c}0.0173 \\
(0.1051)\end{array}$ \\
\hline In education & $\begin{array}{l}0.4388^{* * *} \\
(0.1355)\end{array}$ & $\begin{array}{l}0.4401^{* * *} \\
(0.1355)\end{array}$ & $\begin{array}{l}0.4412^{* * * *} \\
(0.1355)\end{array}$ & $\begin{array}{l}0.4392^{* * *} \\
(0.1355)\end{array}$ & $\begin{array}{l}0.4397^{* * *} \\
(0.1355)\end{array}$ & $\begin{array}{l}0.4408^{* * *} \\
(0.1355)\end{array}$ \\
\hline Retired & $\begin{array}{c}0.0382 \\
(0.0709)\end{array}$ & $\begin{array}{c}0.0410 \\
(0.0709)\end{array}$ & $\begin{array}{c}0.0414 \\
(0.0709)\end{array}$ & $\begin{array}{c}0.0384 \\
(0.0709)\end{array}$ & $\begin{array}{c}0.0379 \\
(0.0709)\end{array}$ & $\begin{array}{c}0.0387 \\
(0.0709)\end{array}$ \\
\hline
\end{tabular}


TABLE 1. Continued

(1) (2)

(3)

(4)

(5)

(6)

Dependent variable: Individual-level support for 'more' or 'much more' government spending (=1) vs. 'the same', 'less', or 'much less' spending $(=0)$ on education

\begin{tabular}{|c|c|c|c|c|c|c|}
\hline \multicolumn{7}{|l|}{ Country-level variables } \\
\hline $\begin{array}{l}\text { Trade openness } \\
\quad(2000) \\
\text { Inequality (2000) }\end{array}$ & $\begin{array}{c}0.0032 \\
(0.0043)\end{array}$ & $\begin{array}{l}0.0082^{* *} \\
(0.0033) \\
0.1120^{* * *} \\
(0.0284)\end{array}$ & $\begin{array}{l}0.0078^{* *} \\
(0.0033) \\
0.1016^{* * *} \\
(0.0312\end{array}$ & & & \\
\hline Public education spending (2000) & & & $-0.1149(0.1544)$ & & & \\
\hline $\begin{array}{l}\text { Trade openness } \\
\quad(2005)\end{array}$ & & & & $\begin{array}{l}0.0020 \\
(0.0050)\end{array}$ & $\begin{array}{l}0.0037 \\
(0.0042)\end{array}$ & $\begin{array}{c}0.0046 \\
(0.0041)\end{array}$ \\
\hline Inequality (2005) & & & & & $\begin{array}{l}0.1074^{* * *} \\
(0.0386)\end{array}$ & $\begin{array}{c}0.0800^{*} \\
(0.0427)\end{array}$ \\
\hline Public education spending (2005) & & & & & & $\begin{array}{l}-0.2246 \\
(0.1762)\end{array}$ \\
\hline Constant & $\begin{array}{l}-0.0914 \\
(0.3995)\end{array}$ & $\begin{array}{l}-3.8019^{* * *} \\
(0.9947)\end{array}$ & $\begin{array}{c}-2.8797^{*} \\
(1.5793)\end{array}$ & $\begin{array}{r}0.0062 \\
(0.4352)\end{array}$ & $\begin{array}{l}-3.2024^{* * *} \\
(1.2129)\end{array}$ & $\begin{array}{l}-1.3443 \\
(1.8629)\end{array}$ \\
\hline \multicolumn{7}{|l|}{ Model fit } \\
\hline $\begin{array}{l}\text { Log likelihood } \\
\text { Rho (macro-level variance) } \\
\text { LR-test rho }\end{array}$ & $\begin{array}{l}-9751.683 \\
.1113 \\
1247.26\end{array}$ & $\begin{array}{l}-9746.1459 \\
.0606 \\
663.60\end{array}$ & $\begin{array}{l}-9745.8737 \\
.0587 \\
595.91\end{array}$ & $\begin{array}{l}-9751.8834 \\
.1136 \\
1250.81\end{array}$ & $\begin{array}{l}-9748.6865 \\
.0803 \\
797.09\end{array}$ & $\begin{array}{l}-9747.9104 \\
.0737 \\
688.99\end{array}$ \\
\hline $\begin{array}{l}\mathrm{N} \text { (individual-level) } \\
\mathrm{N} \text { (country-level) }\end{array}$ & $\begin{array}{l}17,394 \\
17\end{array}$ & $\begin{array}{l}17,394 \\
17\end{array}$ & $\begin{array}{l}17,394 \\
17\end{array}$ & $\begin{array}{l}17,394 \\
17\end{array}$ & $\begin{array}{l}17,394 \\
17\end{array}$ & $\begin{array}{l}17,394 \\
17\end{array}$ \\
\hline
\end{tabular}

${ }^{*} p<0.1 ;{ }^{* *} p<0.05 ;{ }^{* * *} p<0.01$. Standard errors in parentheses. Log likelihood (empty model): -10,957.039 
TABLE 2. Determinants of individual-level support for unemployment spending in 17 countries in 2005/o6, multilevel logit model

(7)

(9)

(10)

(11)

(12)

Dependent variable: Individual-level support for 'more' or 'much more' government spending $(=1)$ vs. 'the same', 'less', or 'much less' spending (=o) on unemployment

Individual-level variables

\begin{tabular}{|c|c|c|c|c|c|c|}
\hline Income & $\begin{array}{l}-0.2011^{* * *} \\
(0.0138)\end{array}$ & $\begin{array}{l}-0.2011^{* * *} \\
(0.0138)\end{array}$ & $\begin{array}{l}-0.2013^{* * *} \\
(0.0138)\end{array}$ & $\begin{array}{l}-0.2011^{* * *} \\
(0.0138)\end{array}$ & $\begin{array}{l}-0.2011^{* * *} \\
(0.0138)\end{array}$ & $\begin{array}{l}-0.2011^{* * *} \\
(0.0138)\end{array}$ \\
\hline Female & $\begin{array}{l}-0.0763^{*} \\
(0.0408)\end{array}$ & $\begin{array}{l}-0.0763^{*} \\
(0.0408)\end{array}$ & $\begin{array}{l}-0.0764^{*} \\
(0.0408)\end{array}$ & $\begin{array}{l}-0.0763^{*} \\
(0.0408)\end{array}$ & $\begin{array}{l}-0.0763^{*} \\
(0.0408)\end{array}$ & $\begin{array}{l}-0.0763^{*} \\
(0.0408)\end{array}$ \\
\hline Education years & $\begin{array}{l}-0.0339^{* * *} \\
(0.0055)\end{array}$ & $\begin{array}{l}-0.0339^{* * *} \\
(0.0055)\end{array}$ & $\begin{array}{l}-0.0339^{* * *} \\
(0.0055)\end{array}$ & $\begin{array}{l}-0.0339^{* * *} \\
(0.0055)\end{array}$ & $\begin{array}{l}-0.0339^{* * *} \\
(0.0055)\end{array}$ & $\begin{array}{l}-0.0339^{* * *} \\
(0.0055)\end{array}$ \\
\hline Age & $\begin{array}{l}0.0364^{* * *} \\
(0.0074)\end{array}$ & $\begin{array}{l}0.0365^{* * *} \\
(0.0074)\end{array}$ & $\begin{array}{l}0.0365^{* * *} \\
(0.0074)\end{array}$ & $\begin{array}{l}0.0364^{* * *} \\
(0.0074)\end{array}$ & $\begin{array}{l}0.0365^{* * *} \\
(0.0074)\end{array}$ & $\begin{array}{l}0.0364^{* * *} \\
(0.0074)\end{array}$ \\
\hline Age (squared) & $\begin{array}{l}-0.0003^{* * *} \\
(0.0001)\end{array}$ & $\begin{array}{l}-0.0003^{* * *} \\
(0.0001)\end{array}$ & $\begin{array}{l}-0.0003^{* * *} \\
(0.0001)\end{array}$ & $\begin{array}{l}-0.0003^{* * *} \\
(0.0001)\end{array}$ & $\begin{array}{l}-0.0003^{* * *} \\
(0.0001)\end{array}$ & $\begin{array}{l}-0.0003^{* * *} \\
(0.0001)\end{array}$ \\
\hline No children & $\begin{array}{l}0.1410^{* * *} \\
(0.0431)\end{array}$ & $\begin{array}{l}0.1414^{* * *} \\
(0.0431)\end{array}$ & $\begin{array}{l}0.1416^{* * *} \\
(0.0431)\end{array}$ & $\begin{array}{l}0.1409^{* * *} \\
(0.0431)\end{array}$ & $\begin{array}{l}0.1418^{* * *} \\
(0.0431)\end{array}$ & $\begin{array}{l}0.1419^{* * *} \\
(0.0431)\end{array}$ \\
\hline Part-time & $\begin{array}{l}-0.0065 \\
(0.0687)\end{array}$ & $\begin{array}{l}-0.0071 \\
(0.0687)\end{array}$ & $\begin{array}{l}-0.0069 \\
(0.0687)\end{array}$ & $\begin{array}{l}-0.0064 \\
(0.0687)\end{array}$ & $\begin{array}{l}-0.0068 \\
(0.0687)\end{array}$ & $\begin{array}{l}-0.0061 \\
(0.0687)\end{array}$ \\
\hline Less than part-time & $\begin{array}{c}0.2118^{* * *} \\
(0.0694)\end{array}$ & $\begin{array}{l}0.2119^{* * *} \\
(0.0694)\end{array}$ & $\begin{array}{l}0.2117^{* * *} \\
(0.0694)\end{array}$ & $\begin{array}{l}0.2120^{* * *} \\
(0.0694)\end{array}$ & $\begin{array}{l}0.2110^{* * *} \\
(0.0694)\end{array}$ & $\begin{array}{c}0.2111^{* * *} \\
(0.0694)\end{array}$ \\
\hline Unemployed & $\begin{array}{l}1.0701^{* * *} \\
(0.1012)\end{array}$ & $c^{1.0704^{* * *}}$ & $\begin{array}{l}1.0697^{* * *} \\
(0.1011)\end{array}$ & $\begin{array}{l}1.0702^{* * *} \\
(0.1012)\end{array}$ & ${ }^{1.0694^{* * *}}{ }^{\text {(o.1011) }}$ & $\begin{array}{l}1.0684^{* * *} \\
(0.1011)\end{array}$ \\
\hline In education & $\begin{array}{l}-0.0901 \\
(0.1502)\end{array}$ & $\begin{array}{l}-0.0893 \\
(0.1502)\end{array}$ & $\begin{array}{l}-0.0889 \\
(0.1502)\end{array}$ & $\begin{array}{l}-0.0900 \\
(0.1502)\end{array}$ & $\begin{array}{l}-0.0894 \\
(0.1502)\end{array}$ & $\begin{array}{l}-0.0880 \\
(0.1502)\end{array}$ \\
\hline Retired & $\begin{array}{l}-0.1388^{*} \\
(0.0765)\end{array}$ & $\begin{array}{l}-0.1379^{*} \\
(0.0765)\end{array}$ & $\begin{array}{l}-0.1384^{*} \\
(0.0765)\end{array}$ & $\begin{array}{l}-0.1388^{*} \\
(0.0765)\end{array}$ & $\begin{array}{l}-0.1390^{*} \\
(0.0765)\end{array}$ & $\begin{array}{l}-0.1402^{*} \\
(0.0765)\end{array}$ \\
\hline
\end{tabular}


TABLE 2. Continued

(7)

(8)

(9)

(10)

(11)

Dependent variable: Individual-level support for 'more' or 'much more' government spending (=1) vs. 'the same', 'less', or 'much less' spending (=o) on unemployment

\begin{tabular}{|c|c|c|c|c|c|c|}
\hline \multicolumn{7}{|l|}{ Country-level variables } \\
\hline $\begin{array}{l}\text { Trade openness } \\
\qquad(2000)\end{array}$ & $\begin{array}{l}0.0050 \\
(0.0052)\end{array}$ & $\begin{array}{c}0.0077 \\
(0.0053)\end{array}$ & $\begin{array}{c}0.0082 \\
(0.0052)\end{array}$ & & & \\
\hline Inequality (2000) & & $\begin{array}{c}0.0614 \\
(0.0452)\end{array}$ & $\begin{array}{c}0.0895^{*} \\
(0.0526)\end{array}$ & & & \\
\hline Public unemployment spending (2000) & & & $0.2914(0.3000)$ & & & \\
\hline $\begin{array}{l}\text { Trade openness } \\
\quad(2005)\end{array}$ & & & & $\begin{array}{l}0.0052 \\
(0.0061)\end{array}$ & $\begin{array}{l}0.0065 \\
(0.0057)\end{array}$ & $\begin{array}{c}0.0038 \\
(0.0057)\end{array}$ \\
\hline Inequality (2005) & & & & & $\begin{array}{c}0.0830 \\
(0.0526)\end{array}$ & $\begin{array}{l}0.1016^{* *} \\
(0.0511)\end{array}$ \\
\hline Public unemployment spending (2005) & & & & & & $\begin{array}{c}0.3729 \\
(0.2513)\end{array}$ \\
\hline Constant & $\begin{array}{l}-1.4153^{* * *} \\
(0.4758) \\
\end{array}$ & $\begin{array}{l}-3.4486^{* *} \\
(1.5665)\end{array}$ & $\begin{array}{l}-4.6549^{* *} \\
(1.9656)\end{array}$ & $\begin{array}{l}-1.4134^{* * *} \\
(0.5179)\end{array}$ & $\begin{array}{l}-3.8909^{* *} \\
(1.6455)\end{array}$ & $\begin{array}{l}-4.6615^{* * *} \\
(1.6357) \\
\end{array}$ \\
\hline \multicolumn{7}{|l|}{ Model fit } \\
\hline Log likelihood & -8497.4426 & -8498.479 & -8499.6412 & -8498.2138 & -8498.6723 & -8499.5441 \\
\hline Rho (macro-level variance) & .1265 & .1407 & .1584 & .1362 & .1430 & .1568 \\
\hline LR-test rho & 1062.02 & 1254.23 & 1493.56 & 961.92 & 1129.89 & 1454.96 \\
\hline$\overline{\mathrm{N} \text { (individual-level) }}$ & 17,142 & 17,142 & 17,142 & 17,142 & 17,142 & 17,142 \\
\hline $\mathrm{N}$ (country-level) & 17 & 17 & 17 & 17 & 17 & 17 \\
\hline
\end{tabular}

${ }^{*} p<0.1 ;{ }^{* *} p<0.05 ;{ }^{* * *} p<0.01$. Standard errors in parentheses. Log likelihood (empty model): -9950.3566 
openness is considerable, although the predicted change seems to be even larger in the case of inequality.

Our analysis of the determinants of support for public spending on unemployment (Table 2) reveals that there is no statistically significant association between trade openness on the macro-level and individual-level support. This is puzzling from the perspective of compensation theory since unemployment benefits are expected to be of greater immediate relevance for employees, especially in times of economic insecurity. This (non-)finding holds irrespective of whether we include trade openness as the only determinant (Table 2, model 7) or in addition to inequality and/or levels of public unemployment spending and irrespective of whether we use time-lagged or simultaneous variables (models 8-12). These findings are at odds with the classical version of the compensation thesis, which needs to be refined in our view. Instead of increasing demand for ex-post compensation, globalisation boosts demand for forward-looking investments such as education.

The control variables perform largely as expected and confirm previous research (Ansell, 2010; Busemeyer, 2012; Busemeyer et al., 2009; Garritzmann, 2015): The determinants of support for education spending differ from support for other kinds of social policies in important ways. Income and educational background are strong and robust negative determinants of support for increased spending on unemployment, as would be expected from the Meltzer-Richard (1981) model, but income and educational background do not have a statistically significant impact on support for education spending. In line with previous research, this underlines that the redistributional effects of education spending are less straightforward compared to other social policies.

A similarity between support for education and unemployment spending is the non-linear effect of age. Individuals initially tend to be more supportive of social spending, but this effect levels out in old age. The magnitude of the squared term is quite small. Women are less supportive of unemployment spending but there is no statistically significant association between gender and support for education spending. Respondents working part-time or less hold similar preferences to those of full-time workers. Not surprisingly, students and pupils are more supportive of increased spending on education, whereas unemployed persons are more supportive of spending on unemployment. Respondents living in a one- or two-person household (our proxy for having no children) are less likely to favour education spending, but support more spending on unemployment. Overall, therefore, the micro-level controls perform in line with our expectations. On the macro-level, confirming the general logic of the Meltzer-Richard (1981) model, a high degree of socio-economic inequality is positively associated with individual-level support for more education and more unemployment spending. In the case of unemployment spending, the effect is significant in a few models only. Model 3 in Table 1 and Model 9 in Table 2 
include levels of public spending in the respective field to test the 'thermostat model' (Soroka and Wlezien, 2010). But the coefficients fail to reach conventional levels of statistical significance.

\section{Robustness}

In order to corroborate our results, we conducted a number of robustness tests. Due to space limitations, we can only summarize these briefly here, but offer detailed results in the Online Appendix. First, we checked whether our results depend on the inclusion or exclusion of certain control variables by estimating different models. For example, on the micro-level we additionally controlled for respondents' ideological self-placement, for their general preference for public spending, and for respondents' exposure to globalisation utilising Walter's (2010a) transformation of Blinder's (2007) offshore-ability index (cf. Online Appendix Table B). Moreover, we also tested whether including respondents' marital status, their religious denomination or service attendance, the size of the city they live in, or the type of employment (public, private, self-employed) alters the results ${ }^{4}$. Moreover, we checked whether using educational degrees rather than education years makes a difference. Yet, none of these tests undermined the main results reported in the text (for all results and detailed interpretation cf. the Online Appendix, particularly Table B).

Second, to further check the macro-level findings, we tested different operationalisations of globalisation, using instead (or in addition) inward and outward foreign direct investment, an index for capital account openness, and the KOF globalisation index (cf. Online Appendix Table C). Additionally, we checked whether the results are stable when we use changes in globalisation rather than levels, which produces the same findings (at a lower level of significance, though). Moreover, we tested whether deindustrialisation rather than globalisation drives the results (Online Appendix Table B). Finally, we also run models only including the macro-level variables to see whether the individual-level variables might mediate the relationship between trade openness and preferences. Again, the main results remained stable and passed these tests.

Third, to make sure the results are not driven by our decision to dichotomize the dependent variable, we used a different dichotomization (distinguishing those 'strongly' in favour against all others), and also used the full, observed variation estimating ordered logit and probit models, partial proportional odds models, and multinomial models. Online Appendix B describes the details of this process and the findings; here we can only briefly mention that the effect of trade openness remained robust. Finally, the results are neither driven by the inclusion or exclusion of survey weights nor affected by missing values.

In sum, the theorised effect of globalisation on demand for public spending seems highly robust as it holds for different variable selections, different 
operationalisations of globalisation, and across different model specifications, and is not affected by missing values or the inclusion of survey weights. This gives us confidence that the reported results are robust, reliable and substantial.

\section{Conclusion}

In our view, the core contribution of this paper is to provide a new perspective on the ongoing debate about the association between economic globalisation and the welfare state: we highlight the importance of the connection between economic openness and demand for human capital investment policies rather than more traditional compensatory social policies. This is a significant extension and modification of the compensation thesis, which has so far mostly focused on the association between exposure to globalisation and individual-level demand for redistribution and traditional forms of social protection. Our analysis shows that this focus needs to be adjusted, because it seems that the public in open economies demands human capital investment rather than compensation via classical social insurance schemes. This may be due to the political influence of affluent middle classes who are more interested in expanding public investment on education rather than expanding unemployment insurance schemes. Alternatively (or additionally), it may be because of 'sociotropic' citizen preferences (Mansfield and Mutz, 2009), i.e. commonly held views that investments in education are more effective in dealing with the challenges of globalisation in the long term compared to social transfers. This article could not fully resolve this issue, but it would be interesting to pursue in future research.

A limitation of our study - related to the limitations of the survey data we use - is that we cannot distinguish between preferences for different types of education. It is plausible to expect that the association between economic globalisation and support for education spending is tighter for types of education with stronger relevance for the labour market, such as vocational training, higher education, or specific types of occupational upgrading policies. Moreover, our study is unfortunately limited in its temporal scope, as we could only exploit data from a single survey wave. While our findings and additional robustness tests lend considerable support to our argument, we were unable to offer a strong causal test. Again, this underlines the high need for comparative survey data including citizens' education policy preferences across countries and over time. This issue should be pursued further in future research, if better survey data is available. Future research could also try to exploit panel data to further study the theorised mechanisms, but unfortunately so far the existing panel studies are country-specific and hardly include (detailed) questions on education policy preferences.

Another related issue, which we could not explore in the present paper, is the question to what extent public preferences actually affect governmental 
decision-making. Some scholars believe in 'social policy by popular demand' (Rehm, 2012; see also Brooks and Manza, 2006; Soroka and Wlezien, 2010). From this rather optimistic perspective, policy-makers are largely responsive to citizens' demands and preferences, even in times of globalisation. From a more pessimistic perspective, it could be argued that economic globalisation has become an increasingly constraining force for policy-making (Busemeyer, 2009; Jahn, 2006; Kwon and Pontusson, 2010). Thus, even if governments wanted to respond to the demands of the public for more spending on education, they could simply not be able to deliver. This would result in a systematic and potentially growing 'mismatch' between public expectations vis-à-vis the welfare state and the policy-makers' ability to meet these demands. Future research on the linkage between public preferences and policy-making would be welcome in order to be able to answer this question. It might well be the case that the compensation and the efficiency theses are both valid, because they capture different aspects (see also Brady et al., 2007; Cerny, 1997; Genschel, 2004; Hays, 2009; Hicks, 1999; Rodrik, 1997). At the same time as the forces of economic globalisation fuel demands for more government support among the public, policy-makers might be increasingly constrained to respond to these demands, potentially contributing to (perception of) democratic mismatches.

\section{Acknowledgements}

We gratefully acknowledge comments by Jason Beckfield, Charlotte Cavaille, Jon Fiva, Jeff Frieden, Dominik Geering, Philipp Genschel, Peter Hall, Irene Menéndez González, Leonce Röth, Carina Schmitt, Olaf van Vliet and the journal's anonymous reviewers as well as participants at the ESPAnet Conference in Oslo and at presentations at the University of Konstanz. We gratefully acknowledge funding by the European Research Council (Starting Grant No. 311769).

\section{Notes}

1 There is more work on the positive association between globalisation and educational investments in developing countries (Ansell, 2008; Benarroch and Pandey, 2012; Rudra and Haggard, 2005; Stasavage, 2005), which is however of limited relevance for the purposes of this paper, since it is mostly concerned with low-income and often non-democratic countries where different dynamics are at work.

2 We show elsewhere (Garritzmann et al., 2018) that - at least for Western Europe education and unemployment benefits can be treated as proxies for respondents' preferences towards social investment and social compensatory policies, respectively. As additional robustness tests, we also analysed attitudes towards health care spending as a second-best operationalisation of compensatory policies and a question on whether respondents think that it is the government's responsibility to 'create jobs' as an additional, albeit rough, measure of social investment (in this case: active labour market policies). While the results are in line with the findings reported here (globalisation increases demand for ALMPs but not for health care), we do not report these for reasons of limited space and for theoretical reasons. In line with the existing literature we believe that health care spending is a less clear-cut example 
for a compensatory policy compared to unemployment benefits. Second, the 'government should create jobs'-question is not specifically about spending. Even though similar questions about government responsibility are regularly used in the welfare state literature to measure attitudes towards the welfare state, we focus on questions related to spending here to ensure comparability. Furthermore, the question does not necessarily measure attitudes for ALMPs, because it could equally be perceived as a measure of Keynesianist attitudes towards public employment or simply demand for more state action. Thus, we focus on unemployment benefits and education spending in the main analysis.

3 Australia, Canada, Denmark, Finland, France, Germany, Ireland, Japan, Netherlands, New Zealand, Norway, Portugal, Spain, Sweden, Switzerland, Great Britain, United States.

4 We thank the reviewers for pointing us at these potential confounders.

\section{Supplementary material}

To view supplementary material for this article, please visit https:/doi.org/ $10.1017 /$ So047279418000569

\section{References}

Ansell, B. W. (2008), 'University Challenges: Explaining Institutional Change in Higher Education', World Politics, 60, 2, 189-230.

Ansell, B. W. (2010), From the Ballot to the Blackboard: The Redistributive Political Economy of Education, Cambridge: Cambridge University Press.

Balcells Ventura, L. (2006), 'Trade Openness and Preferences for Redistribution: A CrossNational Assessment of the Compensation Hypothesis', Business and Politics, 8, 2, 1-50.

Benarroch, M. and Pandey, M. (2012), 'The Relationship Between Trade Openness and Government Size: Does Disaggregating Government Expenditure Matter?' Journal of Macroeconomics, 34, 1, 239-52.

Blinder, A. (2007), 'How Many U.S. Jobs Might be Offshoreable', CEPS Working Paper No. 142. Boix, C. (1998), Political Parties, Growth, and Equality. Conservative and Social Democratic Strategies in the World Economy, New York: Cambridge University Press.

Bonoli, G. (2013), The Origins of Active Social Policy, Oxford: Oxford University Press.

Brady, D., Beckfield, J. and Seeleib-Kaiser, M. (2005), 'Economic Globalization and the Welfare State in Affluent Democracies, 1975-2001', American Sociological Review, 70, 6, 921-48.

Brady, D., Beckfield, J. and Zhao, W. (2007), 'The Consequences of Economic Globalization for Affluent Democracies', Annual Review of Sociology, 33, 1, 313-34.

Brooks, C. and Manza, J. (2006), 'Social Policy Responsiveness in Developed Democracies', American Sociological Review, 71, 3, 474-94.

Burgoon, B. (2001), 'Globalization and Welfare Compensation: Disentangling the Ties that Bind', International Organization, 55, 3, 509-51.

Busemeyer, M. R. (2009), 'From Myth to Reality: Globalisation and Public Spending in OECD Countries Revisited', European Journal of Political Research, 48, 4, 455-82.

Busemeyer, M. R. (2012), 'Inequality and the Political Economy of Education: An Analysis of Individual Preferences in OECD Countries', Journal of European Social Policy, 22, 3, 219-40.

Busemeyer, M. R., Goerres, A. and Weschle, S. (2009), 'Attitudes Towards Redistributive Spending in an Era of Demographic Ageing: The Rival Pressures From Age and Income in 14 OECD Countries', Journal of European Social Policy, 19, 3, 195-212.

Cameron, D. R. (1978), 'The Expansion of the Public Economy: A Comparative Analysis', American Political Science Review, 72, 4, 1243-61.

Castles, F. G. (2004), The Future of the Welfare State: Crisis Myths and Realities, Oxford: Oxford University Press.

Cerny, P. G. (1997), 'Paradoxes of the Competition State: The Dynamics of Political Globalization', Government and Opposition, 32, 2, 251-74. 
Dreher, A., Gaston, N. and Martens, P. (2008), Measuring Globalisation - Gauging Its Consequences, New York: Springer.

Emmenegger, P., Marx, P. and Schraff, D. (2015), 'Labour Market Disadvantage, Political Orientations and Voting: How Adverse Labour Market Experiences Translate into Electoral Behaviour', Socio-Economic Review, 13, 2, 189-213.

Garrett, G. (1998), Partisan Politics in the Global Economy, Cambridge: Cambridge University Press.

Garrett, G. (2001), 'Globalization and Government Spending around the World', Studies in Comparative International Development, 35, 4, 3-29.

Garrett, G. and Mitchell, D. (2001), 'Globalization, Government Spending and Taxation in the OECD', European Journal of Political Research, 39, 2, 145-77.

Garritzmann, J. L. (2015), 'Attitudes towards Student Support. How Positive Feedback-Effects Prevent Change in the Four Worlds of Student Finance', Journal of European Social Policy, $25,2,139-158$.

Garritzmann, J. L., Busemeyer, M. R. and Neimanns, E. (2018), 'Public Demand for Social Investment: New Supporting Coalitions for Welfare State Reform in Western Europe?', Journal of European Public Policy, 25, 6, 844-61.

Genschel, P. (2002), 'Globalization, Tax Competition, and the Welfare State', Politics \& Society, $30,2,245-75$.

Genschel, P. (2004), 'Globalization and the Welfare State: A Retrospective', Journal of European Public Policy, 11, 4, 613-36.

Hays, J. C., Ehrlich, S. D. and Peinhardt, C. (2005), 'Government Spending and Public Support for Trade in the OECD: An Empirical Test of the Embedded Liberalism Thesis', International Organization, 59, 473-94.

Hays, J. C. (2009), Globalization and the New Politics of Embedded Liberalism, Oxford: Oxford University Press.

Hemerijck, A. (2013), Changing Welfare States, Oxford: Oxford University Press.

Hicks, A. (1999), Social Democracy and Welfare Capitalism: A Century of Income Security Politics, New York: Carnell.

ISSP Research Group (2008), International Social Survey Programme: Role of Government IVISSP 2006. Cologne: GESIS Data Archive. ZA470o Data file Version 1.o.o.

Iversen, T. (2001), 'The Dynamics of Welfare State Expansion: Trade Openness, Deindustrialization and Partisan Politics', in P. Pierson (ed), The New Politics of the Welfare State, Oxford: Oxford University Press, 45-79.

Iversen, T. and Cusack, T. R. (2000), 'The Causes of Welfare State Expansion: Deindustrialization or Globalization?', World Politics, 52, 3, 313-49.

Jahn, D. (2006), 'Globalization as "Galton's Problem": The Missing Link in the Analysis of Diffusion Patterns in Welfare State Development', International Organization, 6o, 2, 40131.

Jensen, C. (2011), 'Capitalist Systems, Deindustrialization, and the Politics of Public Education', Comparative Political Studies, 44, 4, 412-35.

Jensen, C. (2014), The Right and the Welfare State, Oxford: Oxford University Press.

Katzenstein, P. J. (1985), Small States in World Markets: Industrial Policy in Europe, Ithaca: Cornell University Press.

Kurzer, P. (1991), 'Unemployment in Open Economies: The Impact of Trade, Finance, and European Integration', Comparative Political Studies, 24, 1, 3-30.

Kwon, H. Y. and Pontusson, J. (2010), 'Globalization, Labor Power and Partisan Politics Revisited', Socio-Economic Review, 8, 2, 251-81.

Leibrecht, M., Klien, M. and Onaran, O. (2011), 'Globalization, welfare regimes and social protection expenditures in Western and Eastern European countries', Public Choice, 148, $569-94$.

Mansfield, E. D. and Mutz, D. C. (2009), 'Support for Free Trade: Self-Interest, Sociotropic Politics, and out-Group Anxiety', International Organization, 63, $425-57$. 
Marshall, J. and Fisher, S. D. (2015), 'Compensation or Constraint? How Different Dynamics of Economic Globalization Affect Government Spending and Electoral Turnout', British Journal of Political Science, 45, 2, 353-389.

Mayda, A. M. and Rodrik, D. (2005), 'Why Are Some People (and Countries) More Protectionist Than Others?', European Economic Review, 49, 1393-430.

Meinhard, S. and Potrafke, N. (2012), 'The Globalization-Welfare State Nexus Reconsidered', Review of International Economics, 20, 2, 271-87.

Meltzer, A. H. and Richard, S. F. (1981), 'A Rational Theory of the Size of Government', Journal of Political Economy, 89, 5, 914-27.

Morel, N., Palier, B. and Palme, J. (2012), Towards a Social Investment Welfare State? Ideas, Policies, and Challenges, Bristol: Policy Press.

Potrafke, N. (2009), 'Did globalization restrict partisan politics? An empirical evaluation of social expenditures in a panel of OECD countries', Public Choice, 140, 105-25.

Rehm, P. (2012), 'Social Policy by Popular Demand', World Politics, 63, 2, 271-99.

Rodrik, D. (1997), Has Globalization Gone Too Far? Washington, D.C.: Institute for International Economics.

Rodrik, D. (1998), 'Why Do More Open Economies Have Bigger Governments?', Journal of Political Economy, 106, 5, 997-1032.

Rudra, N. and Haggard, S. (2005), 'Globalization, Democracy, and Effective Welfare Spending in the Developing World', Comparative Political Studies, 38, 9, 1015-1049.

Schaffer, L. and Spilker, G. (2016), 'Adding Another Level: Individual Responses to Globalization and Government Welfare Policies', Political Science Research and Methods, 4, 2, 399-426.

Scharpf, F. W. (1991), Crisis and Choice in European Social Democracy, Ithaca: Cornell University Press.

Scheve, K. and Slaughter, M. J. (2004), 'Economic Insecurity and the Globalization of Production', American Journal of Political Science, 48, 4, 662-74.

Solt, F. (2009), 'Standardizing the World Income Inequality Database', Social Science Quarterly, 90, 2, 231-42.

Soroka, S. N. and Wlezien, C. (2010), Degrees of Democracy: Politics, Public Opinion, and Policy, New York: Cambridge University Press.

Starke, P., Kaasch, A. and van Hooren, F. (2014), 'Political Parties and Social Policy Responses to Global Economic Crises: Constrained Partisanship in Mature Welfare States', Journal of Social Policy, 43, 2, 225-246.

Stasavage, D. (2005), 'Democracy and Education Spending in Africa', American Journal of Political Science, 49, 2, 343-358.

Svallfors, S. (1997), 'Worlds of Welfare and Attitudes to Redistribution: A Comparison of Eight Western Nations', European Sociological Review, 13, 3, 283-304.

Swank, D. (2002), Global Capital, Political Institutions, and Policy Change in Developed Welfare States, Cambridge: Cambridge University Press.

Taylor-Gooby, P. (2002), 'The Silver Age of the Welfare State: Perspectives on Resilience', Journal of Social Policy, 31, 4, 597-621.

Van Kersbergen, K. and Hemerijck, A. (2012), 'Two Decades of Change in Europe: The Emergence of the Social Investment State', Journal of Social Policy, 41, 3, 475-492.

Van Oorschot, W. (2006), 'Making the Difference in Europe: Deservingness Perceptions among Citizens of European Welfare States', Journal of European Social Policy, 16, 1, 23-42.

Walter, S. (2010a), 'Globalization and the Demand-Side of Politics: How globalisation shapes individual perceptions of labor market risk and policy preferences', Paper presented at IPES Annual Conference, Harvard University, November 12-13, 2010.

Walter, S. (2010b), 'Globalization and the Welfare State: Testing the Microfoundations of the Compensation Hypothesis', International Studies Quarterly, 54, 2, 403-26.

Walter, S. (2017), 'Globalization and the Demand-Side of Politics: How Globalisation Shapes Labor Market Risk Perceptions and Policy Preferences', Political Science Research and Methods, 5, 1, 55-80. 